\title{
Sensory Properties and Microbial Characteristics of Cookies Prepared from Refined Wheat Flour Supplemented with Sweet Potato Flour and Whey Protein Concentrate
}

\author{
Blessy Sagar Seelam ${ }^{1^{*}}$, John David ${ }^{1}$, Neha Singh $^{1}$ and Sonia Morya ${ }^{1}$ \\ ${ }^{1}$ Warner College of Dairy Technology, Sam Higginbottom University of Agriculture, Technology and \\ Sciences, Allahabad 21107, India.
}

\begin{abstract}
Authors' contributions
This work was carried out in collaboration between all authors. Authors BSS and JD designed the study, performed the statistical analysis, wrote the protocol and wrote the first draft of the manuscript.

Author NS managed the analyses of the study. Author SM managed the literature searches. All

authors read and approved the final manuscript.

Article Information

DOI: $10.9734 /$ IJBCRR/2017/33992

Editor(s):

(1) Fatih Oz, Food Engineering Department, Agriculture Faculty, Ataturk University, Turkey.

Reviewers:

(1) Shivani Pathania, Teagasc Food Research Centre, Republic of Ireland.

(2) Uttara Singh, Panjab University, India. (3) Sherif Ramzy Mohamed, National Research Centre, Egypt. Complete Peer review History: http://www.sciencedomain.org/review-history/19911
\end{abstract}

Original Research Article

Received $8^{\text {th }}$ May 2017

Accepted $28^{\text {th }}$ June 2017

Published $7^{\text {th }}$ July 2017

ABSTRACT

A study was conducted for sensory analysis and microbial assay for the cookies supplemented with refined wheat flour, sweet potato flour and whey proteins concentrate (WPC-80). The cookies made were nutritious products for all peoples. The product on the whole composed of sweet potato flour, whey protein concentrate (WPC-80), refined wheat flour and other ingredients such as butter and sugar. The product was made with different formulations. Sensory evaluation was done for acceptability of the product and microbial study was conducted for the developed cookies. Results from sensory analysis revealed that all treatment combinations are in acceptable level. Among all, $\mathrm{T}_{3} \mathrm{HT} 1$ (20\% SPF and 20\% WPC) scored best in overall acceptability. The SPC ranges from $1.400 \pm 0.548$ to $4.400 \pm 0.548$ from $0^{\text {th }}$ to $30^{\text {th }}$ days, Yeast and mould was NIL in $0^{\text {th }}$ and $15^{\text {th }}$ day on $30^{\text {th }}$ it was recorded. Coli forms count is NIL in $0^{\text {th }}$ day and it was recorded in $15^{\text {th }}$ and $30^{\text {th }}$ days for different treatment combination. 
Keywords: Sweet potato flour; whey protein concentrate; cookies sensory evaluation; microbial assay.

\section{INTRODUCTION}

The sweet potato Ipomoea batatas (L.) belongs to the Convolvulaceae. Sweet potato is among the world's most important and under-exploited crop [1]. Sweet-potato (Ipomoea batatas L) is the seventh most important food crop in the world. It is grown in many tropical and subtropical regions. Among the world's major food crops, sweet-potato produces the highest amount of edible energy/ha/day [2]. Sweet-potato flour can serve as a source of energy and nutrients (carbohydrates, beta-carotene (pro-vitamin A), minerals $(\mathrm{Ca}, \mathrm{P}, \mathrm{Fe}$, and $\mathrm{K})$, and can add natural sweetness, color, flavor, and dietary fiber to processed food products. Because of the distinct properties, the use of sweet-potato flour in the preparation of bread is restricted; Biscuits are baked dry products, usually with a golden brown crust and crispy texture [3].

Whey was previously considered as waste because of its potential for spoilage. Now days however it is no longer considered as a waste product but treasure of nutritionally rich whey proteins. WPC has many health benefits and clinical importance. WPC is useful in the treatment of various diseases and health problems such as cancer and high cholesterol [4]. It is effective in trauma, burn and renal failure $[5,6]$. It has the ability to act as antibacterial and antiviral agent [7]. Whey proteins are easily and readily digested and therefore useful in post operative care of patients. Its use is beneficial in diabetes, cardiac ailment, liver problem, arthritis, gout and antihypertensive. It is antitumor agent and giving antioxidant effect [8,9]. WPC has immune-enhancing property due to which it can be used in treating HIV patients. Whey protein also acts as a sport, food as whey proteins helps in speedy repairing of injured and torn muscle during practice and performance $[10,11]$. Whey proteins provide excellent nutritional values in nutrition, foods formulated for infant, kids, adults and old aged people as growth tonic for body health maintenance.

Bakery industry in India is considered as one of the major food processing industry with an annual demand of over 2758 MT [11]. (Ministry of Food Processing Industries, 2013). India is known to be the second largest manufacturer of biscuits, first being USA. Bakery products are the most popular food consumed by all age groups and are gaining popularity as processed foods because of their availability, ready to eat convenience, and comparatively good shelf life.

As discussed above, it is clear that sweet potato flour is rich in dietary fiber, functional fiber. Whey protein concentrate is rich in available protein content, high calcium and minerals, it can be considered as fortification for plain cookies.

\section{MATERIALS AND METHODS}

Sweet potatoes were procured locally from the field after harvesting. Roots were washed, trimmed and cured to make them free from soil and other foreign materials, rotting, insect damage and washed with common salt and made into slices, dried by using a tray drier at $60^{\circ} \mathrm{C}$ for $6 \mathrm{~h}$ and then Grinding, Sieving on 70 mesh [2]. The prepared Sweet potato flour Packed in HDPE and stored for 6 months or more in sealed containers.

WPC were procured from Mahan proteins Itd., Delhi, India. Refined wheat flour, sugar, shortening (Amul Butter) were procured from local market of Allahabad (India) and kept at room temperature for further use. All chemicals used were of analytical grade.

\subsection{Preparation Dough for Cookies}

The dough was made in a laboratory mixer. Fat and sugar was creamed in a mixer with a flat beater for 2 min at slow speed. Sodium chloride was added to the resulting cream, and mixed for $5 \mathrm{~min}$ at high speed to obtain a homogeneous mixture. Finally, flour containing various proportions of sweet potato flour, and whey protein concentrate (WPC-80), which had been sieved twice with baking powder was added, and mixed for $3 \mathrm{~min}$ at medium speed. The dough preparation, sheeting and moulding followed by different heat treatments like baking at $180^{\circ} \mathrm{C}$ for 15 mins, microwave heating at $180^{\circ} \mathrm{C}$ for 10 mins and frying at $180^{\circ} \mathrm{C} 8$ mins. Combination treatment with different heat treatments is given in the following Table 2.1.

\subsection{Sensory Evaluation}

The evaluation was done by 5 trained and semi trained panelists at Warner College of Dairy Technology, SHUATS. Judgments for developed cookies were made through rating products on a5 point Hedonic scale [12]. With corresponding descriptive terms ranging from 5 'like extremely' 
Table 2.1. Treatment combination of different cookies

\begin{tabular}{lllll}
\hline Heat treatments & $\begin{array}{l}\text { Treatment } \\
\text { combinations }\end{array}$ & $\begin{array}{l}\text { Refined wheat } \\
\text { flour }\end{array}$ & $\begin{array}{l}\text { Sweet potato } \\
\text { flour }\end{array}$ & $\begin{array}{l}\text { Whey protein concentrate } \\
\text { (WPC-80) }\end{array}$ \\
\hline Baking at $180^{\circ} \mathrm{C}$ & $\mathrm{T}_{0} \mathrm{HT}_{1}$ & 100 & - & - \\
for 15 mins. & $\mathrm{T}_{1} \mathrm{HT}_{1}$ & 60 & 40 & - \\
& $\mathrm{T}_{2} \mathrm{HT}_{1}$ & 60 & 30 & 10 \\
& $\mathrm{~T}_{3} \mathrm{HT}_{1}$ & 60 & 20 & 20 \\
& $\mathrm{~T}_{4} \mathrm{HT}_{1}$ & 60 & 10 & 30 \\
& $\mathrm{~T}_{5} \mathrm{HT}_{1}$ & 60 & - & 40 \\
\hline Microwave & $\mathrm{T}_{0} \mathrm{HT}_{2}$ & 100 & - & - \\
heating at $180^{\circ} \mathrm{C}$ & $\mathrm{T}_{1} \mathrm{HT}_{2}$ & 60 & 40 & - \\
for 10 mins. & $\mathrm{T}_{2} \mathrm{HT}_{2}$ & 60 & 30 & 10 \\
& $\mathrm{~T}_{3} \mathrm{HT}_{2}$ & 60 & 20 & 20 \\
& $\mathrm{~T}_{4} \mathrm{HT}_{2}$ & 60 & 10 & 30 \\
\hline Frying at $180^{\circ} \mathrm{C}$ & $\mathrm{T}_{5} \mathrm{HT}_{2}$ & 60 & - & 40 \\
8 mins. & $\mathrm{T}_{0} \mathrm{HT}_{3}$ & 100 & - & - \\
& $\mathrm{T}_{1} \mathrm{HT}_{3}$ & 60 & 40 & - \\
& $\mathrm{T}_{2} \mathrm{HT}_{3}$ & 60 & 30 & 10 \\
& $\mathrm{~T}_{3} \mathrm{HT}_{3}$ & 60 & 20 & 20 \\
& $\mathrm{~T}_{4} \mathrm{HT}_{3}$ & 60 & 10 & 30 \\
& $\mathrm{~T}_{5} \mathrm{HT}_{3}$ & 60 & - & 40 \\
\hline
\end{tabular}

to 1 'dislike extremely' having different quality attributes such as colour and appearance, body and texture, flavor and taste, mouth feel and over-all acceptability.

\subsection{Microbial Analaysis}

Standard plate count, Yeast and mould and Coli form were determined by using serial dilution pour plate method. The number of colonies appeared on dilution plates were counted, averaged and reported as cells per gram (cfu/gm) of the sample.

\subsection{Statistical Analysis}

To determine the statistical significance of sensory and microbial evaluation of cookies were analyzed using minitab18 software by ANOVA followed by Tukey's test (one-way) at a 5\% significance level. All values are expressed as mean and standard deviation of five parallel measurements.

\section{RESULTS AND DISCUSSION}

\subsection{Sensory Properties of Different Types of Cookies}

Organoleptic evaluation offers the opportunity to obtain a complete analysis of various properties of food as perceived by human senses. Sensory evaluation is an important and best method for evaluating the organoleptic properties of various products which provide quality measure and production control. To select the sensory attractive cookies prepared by different combinations of sweet potato and whey protein concentrate (WPC-80), were subjected to sensory evaluation using 5 point hedonic scale. Colour and appearance, body and texture ,flavor and taste, mouth feel and over all acceptability were the parameters studied for selecting the better product among the different treatment combinations. Oraganoleptic evaluation of developed cookies was carried out by a panel of 5 semi trained panel members and best product was selected based on the results from the score card. The results of various quality attributes are present in the Tables 3.1a, 3.1b and 3.1c and Fig. 3.1.

The results of sensory evaluation of cookies indicated that among the different treatment combinations, $\mathrm{T}_{1} \mathrm{HT}_{3}(4.900 \pm 0.224)$ was better acceptable in terms of colour and appearance. $\mathrm{T}_{0}$ $\mathrm{HT}_{3}(4.600 \pm 0.548)$ for flavour \& taste, $\mathrm{T}_{3} \mathrm{HT}_{1}$ (4.700 \pm 0.274$)$ for body and texture, $\mathrm{T}_{3} \mathrm{HT}_{1}$

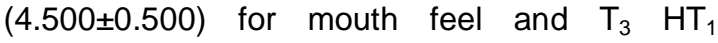
$(4.800 \pm 0.274)$ for over- all acceptability.

The sensory evaluations for three heat treatments were good in taste. The body and texture, consistency of fried cookies were reported to be too soft because of porous structure developed during frying process; heat is transferred from hot oil to the product surface by convection and from the surface to the centre 
Table 3.1a. Sensory properties of baked cookies

\begin{tabular}{llllll}
\hline $\begin{array}{l}\text { Treatments } \\
\text { combinations }\end{array}$ & $\begin{array}{l}\text { Colour and } \\
\text { appearance } \\
\text { of cookies }\end{array}$ & $\begin{array}{l}\text { Flavour and } \\
\text { taste }\end{array}$ & $\begin{array}{l}\text { Body and } \\
\text { texture of } \\
\text { cookies }\end{array}$ & Mouth feel & $\begin{array}{l}\text { Over all } \\
\text { acceptability }\end{array}$ \\
\hline $\mathrm{T}_{0} \mathrm{HT}_{1}$ & $3.600 \pm 0.894^{\mathrm{ab}}$ & $3.400 \pm 0.548^{\mathrm{a}, \mathrm{b}}$ & $3.000 \pm 0.000^{\mathrm{c}}$ & $3.600 \pm 0.548^{\mathrm{a}, \mathrm{b}}$ & $3.200 \pm 0.447^{\mathrm{c}}$ \\
$\mathrm{T}_{1} \mathrm{HT}_{1}$ & $4.600 \pm 0.548^{\mathrm{a}}$ & $4.200 \pm 0.447^{\mathrm{a}}$ & $4.400 \pm 0.548^{\mathrm{a}}$ & $4.400 \pm 0.548^{\mathrm{a}, \mathrm{b}}$ & $4.600 \pm 0.548^{\mathrm{a}, \mathrm{b}}$ \\
$\mathrm{T}_{2} \mathrm{HT}_{1}$ & $3.400 \pm 0.548^{\mathrm{b}}$ & $3.600 \pm 0.548^{\mathrm{a}, \mathrm{b}}$ & $3.400 \pm 0.548^{\mathrm{b}, \mathrm{c}}$ & $3.400 \pm 0.548^{\mathrm{b}}$ & $3.600 \pm 0.548^{\mathrm{b}, \mathrm{c}}$ \\
$\mathrm{T}_{3} \mathrm{HT}_{1}$ & $4.600 \pm 0.224^{\mathrm{a}}$ & $4.200 \pm 0.447^{\mathrm{a}}$ & $4.700 \pm 0.274^{\mathrm{a}}$ & $4.500 \pm 0.500 \mathrm{a}$ & $4.800 \pm 0.274^{\mathrm{a}}$ \\
$\mathrm{T}_{4} \mathrm{HT}_{1}$ & $3.200 \pm 0.447^{\mathrm{b}}$ & $2.700 \pm 0.447^{\mathrm{b}}$ & $2.900 \pm 0.742^{\mathrm{c}}$ & $3.400 \pm 0.548^{\mathrm{b}}$ & $3.300 \pm 0.671^{\mathrm{c}}$ \\
$\mathrm{T}_{5} \mathrm{HT}_{1}$ & $4.200 \pm 0.274^{\mathrm{ab}}$ & $4.100 \pm 0.742^{\mathrm{a}}$ & $4.100 \pm 0.548^{\mathrm{a}, \mathrm{b}}$ & $4.100 \pm 0.548^{\mathrm{a}, \mathrm{b}}$ & $4.100 \pm 0.548^{\mathrm{a}, \mathrm{b}, \mathrm{c}}$ \\
\hline \multicolumn{5}{c}{ Same letters within the same column do not differ significantly $(p<0.05)$ according to Tukey's test }
\end{tabular}

Table 3.1b. Sensory properties of microwaved cookies

\begin{tabular}{llllll}
\hline $\begin{array}{l}\text { Treatments } \\
\text { combinations }\end{array}$ & $\begin{array}{l}\text { Colour and } \\
\text { appearance of } \\
\text { cookies }\end{array}$ & $\begin{array}{l}\text { Flavour and } \\
\text { taste }\end{array}$ & $\begin{array}{l}\text { Body and } \\
\text { texture of } \\
\text { cookies }\end{array}$ & Mouth feel & $\begin{array}{l}\text { Over all } \\
\text { acceptability }\end{array}$ \\
\hline $\mathrm{T}_{0} \mathrm{HT}_{2}$ & $3.600 \pm 0.548^{\mathrm{c}, \mathrm{d}}$ & $3.200 \pm 0.447 \mathrm{~b}$ & $3.600 \pm 0.548^{\mathrm{a}}$ & $4.000 \pm 0.000 \mathrm{a}, \mathrm{b}$ & $4.000 \pm 0.000^{\mathrm{a}, \mathrm{b}}$ \\
$\mathrm{T}_{1} \mathrm{HT}_{2}$ & $4.500 \pm 0.354^{\mathrm{a}}$ & $3.300 \pm 0.274 \mathrm{~b}$ & $4.000 \pm 0.612^{\mathrm{a}}$ & $4.000 \pm 0.612 \mathrm{a}, \mathrm{b}$ & $4.400 \pm 0.224^{\mathrm{a}}$ \\
$\mathrm{T}_{2} \mathrm{HT}_{2}$ & $4.200 \pm 0.274^{\mathrm{a}, \mathrm{b}, \mathrm{c}}$ & $3.600 \pm 0.548 \mathrm{a}, \mathrm{b}$ & $3.900 \pm 0.224^{\mathrm{a}}$ & $4.100 \pm 0.224 \mathrm{a}, \mathrm{b}$ & $4.200 \pm 0.274^{\mathrm{a}, \mathrm{b}}$ \\
$\mathrm{T}_{3} \mathrm{HT}_{2}$ & $4.400 \pm 0.548^{\mathrm{a}, \mathrm{b}}$ & $4.400 \pm 0.548 \mathrm{a}$ & $4.100 \pm 0.548^{\mathrm{a}}$ & $4.400 \pm 0.548 \mathrm{a}$ & $4.300 \pm 0.447^{\mathrm{a}}$ \\
$\mathrm{T}_{4} \mathrm{HT}_{2}$ & $3.700 \pm 0.274^{\mathrm{b}, \mathrm{c}, \mathrm{d}}$ & $3.700 \pm 0.447 \mathrm{a}, \mathrm{b}$ & $3.500 \pm 0.500^{\mathrm{a}}$ & $3.600 \pm 0.418 \mathrm{a}, \mathrm{b}$ & $3.700 \pm 0.274^{\mathrm{b}}$ \\
$\mathrm{T}_{5} \mathrm{HT}_{2}$ & $3.000 \pm 0.000^{\mathrm{d}}$ & $3.100 \pm 0.224 \mathrm{~b}$ & $2.400 \pm 0.418^{\mathrm{b}}$ & $3.400 \pm 0.418 \mathrm{~b}$ & $2.700 \pm 0.274^{\mathrm{c}}$ \\
\hline \multicolumn{5}{c}{ Same letters within the same column do not differ significantly $(p<0.05)$ according to Tukey's test }
\end{tabular}

Table 3.1c. Sensory properties of fried cookies

\begin{tabular}{llllll}
\hline $\begin{array}{l}\text { Treatments } \\
\text { combinations }\end{array}$ & $\begin{array}{l}\text { Colour and } \\
\text { appearance } \\
\text { of cookies }\end{array}$ & $\begin{array}{l}\text { Flavour and } \\
\text { taste }\end{array}$ & $\begin{array}{l}\text { Body and } \\
\text { texture } \\
\text { of cookies }\end{array}$ & Mouth feel & $\begin{array}{l}\text { Over all } \\
\text { acceptability }\end{array}$ \\
\hline $\mathrm{T}_{0} \mathrm{HT}_{3}$ & $4.400 \pm 0.548^{\mathrm{a}, \mathrm{b}}$ & $4.600 \pm 0.548^{\mathrm{a}}$ & $4.200 \pm 0.837^{\mathrm{a}, \mathrm{b}}$ & $4.400 \pm 0.548^{\mathrm{a}}$ & $4.600 \pm 0.548^{\mathrm{a}}$ \\
$\mathrm{T}_{1} \mathrm{HT}_{3}$ & $4.900 \pm 0.224^{\mathrm{a}}$ & $3.200 \pm 0.274^{\mathrm{b}}$ & $4.400 \pm 0.418^{\mathrm{a}, \mathrm{b}}$ & $3.600 \pm 0.418^{\mathrm{a}, \mathrm{b}}$ & $4.400 \pm 0.418^{\mathrm{a}}$ \\
$\mathrm{T}_{2} \mathrm{HT}_{3}$ & $3.900 \pm 0.742^{\mathrm{a}, \mathrm{b}, \mathrm{c}}$ & $3.900 \pm 0.742^{\mathrm{a}, \mathrm{b}}$ & $4.600 \pm 0.548^{\mathrm{a}}$ & $4.200 \pm 0.447^{\mathrm{a}}$ & $4.200 \pm 0.837^{\mathrm{a}}$ \\
$\mathrm{T}_{3} \mathrm{HT}_{3}$ & $3.300 \pm 0.274^{\mathrm{c}, \mathrm{d}}$ & $3.700 \pm 0.447^{\mathrm{a}, \mathrm{b}}$ & $4.000 \pm 0.000^{\mathrm{a}, \mathrm{b}}$ & $3.600 \pm 0.418^{\mathrm{a}, \mathrm{b}}$ & $3.700 \pm 0.274^{\mathrm{a}, \mathrm{b}}$ \\
$\mathrm{T}_{4} \mathrm{HT}_{3}$ & $3.800 \pm 0.837^{\mathrm{b}, \mathrm{c}, \mathrm{d}}$ & $3.600 \pm 0.894^{\mathrm{a}, \mathrm{b}}$ & $3.300 \pm 0.975^{\mathrm{b}, \mathrm{c}}$ & $3.600 \pm 0.894^{\mathrm{a}, \mathrm{b}}$ & $3.700 \pm 0.837^{\mathrm{a}, \mathrm{b}}$ \\
$\mathrm{T}_{5} \mathrm{HT}_{3}$ & $2.800 \pm 0.274^{\mathrm{d}}$ & $2.800 \pm 0.447^{\mathrm{b}}$ & $2.400 \pm 0.418^{\mathrm{c}}$ & $3.000 \pm 0.000^{\mathrm{b}}$ & $2.900 \pm 0.224^{\mathrm{b}}$ \\
\hline \multicolumn{5}{c}{ Same letters within the same column do not differ significantly $(p<0.05)$ according to Tukey's test }
\end{tabular}

by conduction. The liquid water moves from inside of the fries to the evaporation zone leaving the product from the surface as vapour. Some of this vapour though, may remain trapped within the pores due to restrictive intercellular diffusion. The vapour in this confined space will expand and become superheated, distorting the pore walls and contributing to total porosity $[13,14]$. As the sweet potato flour concentration increased, the softness is decreased. It was reported in baking and microwave heat treatments were almost same but crust is for in baked cookies. One of the most important changes is the product evolving from semi-viscous dough to a solid alveolar structure at the end of baking. Air bubbles, introduced during the mixing of ingredients expand within the product during baking and contribute also to the volume expansion although to a lesser extent. Finally, upon baking the water evaporation/condensation within the product structure results in a significant moisture loss qualified as moderate drying.

Another important reaction influencing the quality of baked product is the appropriate brown color development on the surface by sugar caramelization, Maillard reactions, starch dextrination and/roasting of protein network [15]. Where as in micro wave heating process avoids the problem of crust formation and surface 
browning. In contrast to conventional baking microwave heating inactivates this enzyme fast enough (due to a fast and uniform temperature rise in the whole product) to prevent the starch from extensive breakdown, and develops sufficient $\mathrm{CO} 2$ and steam to produce a highly porous [16].

Crispness is more in $40 \%$ sweet potato flour incorporated cookies $\left(\mathrm{T}_{3} \mathrm{HT}_{1}, \mathrm{~T}_{3} \mathrm{HT}_{2}\right)$ as per the sensory evaluation. The overall acceptability of the cookies was almost similar in baking and microwave heat treatments.

\subsection{Microbiological Assay of Different Types of Cookies}

The obtained results for standard plate count (SPC), Yeast and mould and Coli forms in developed cookies are presented in Tables 3.2a, $3.2 \mathrm{~b}$ and $3.2 \mathrm{c}$. On $0^{\text {th }}$ day the SPC for baked cookies was more in $\mathrm{T}_{5} \mathrm{HT}_{1}(3.600 \pm 0.894)$ which was recorded in $40 \%$ whey protein concentrate (WPC-80), incorporated cookies and least in $\mathrm{T}_{2}$ $\mathrm{HT}_{1}$ as the days increased standard plate count (SPC) gradually increased. Yeast and mould count was recorded nil in $0^{\text {th }}$ and $15^{\text {th }}$ where as on $30^{\text {th }} T_{5} \mathrm{HT}_{1}$ was recorded as $0.200 \pm 0.00$ where as in Coli forms was highest on $30^{\text {th }}$ day in $\mathrm{T}_{1} \mathrm{HT}_{1}(2.800 \pm 0.447)$ and the least was recorded on $0^{\text {th }}$ day $(\mathrm{Nil})$.

In microwave treated cookies SPC is high in $\mathrm{T}_{1} \mathrm{HT}_{2}(2.200 \pm 0.837)$ and $\mathrm{T}_{3} \mathrm{HT}_{2}(2.200 \pm 0.837)$ and least in $\mathrm{T}_{2} \mathrm{HT}_{2}(1.400 \pm 0.548)$ in on $0^{\text {th }}$ day. Yeast and mould count was recorded nil in $0^{\text {th }}$ and $15^{\text {th }}$ where as on $30^{\text {th }} \mathrm{T}_{5} \mathrm{HT}_{5}$ was recorded as $0.25 \pm 0.434$. Coli form is nil on $0^{\text {th }}$ day and $15^{\text {th }}$ day it is recorded in $\mathrm{T}_{5} \mathrm{HT}_{2}(1.520 \pm 0.449)$. On $30^{\text {th }}$ day coli form was recorded more which is highest in $\mathrm{T}_{3} \mathrm{HT}_{2}(2.360 \pm 0.590)$ and least in $\mathrm{T}_{4} \mathrm{HT}_{2}$

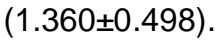

In fried cookies SPC, Yeast and mould and Coli form is recorded high as compared to the baked and microwave treated cookies. SPC ranges from $1.600 \pm 0.548\left(\mathrm{~T}_{2} \mathrm{HT}_{3}\right)$ to $4.400 \pm 0.548\left(\mathrm{~T}_{5}\right.$ $\mathrm{HT}_{3}$ ) on $0^{\text {th }}$ day. SPC increased on 15 to $30^{\text {th }}$ day. Yeast and mould recorded nil on $0^{\text {th }}$ and $15^{\text {th }}$ day where as on $30^{\text {th }}$ it is recorded in $\mathrm{T}_{5} \mathrm{HT}_{3}$ $(0.1200 \pm 0.548)$ coli form is more on $30^{\text {th }}$ day as compared to $0^{\text {th }}$ and $15^{\text {th }}$ day. It was observed that the all the treatment combinations values are still within acceptable limit.

\section{Sensory evaluation of developed cookies}
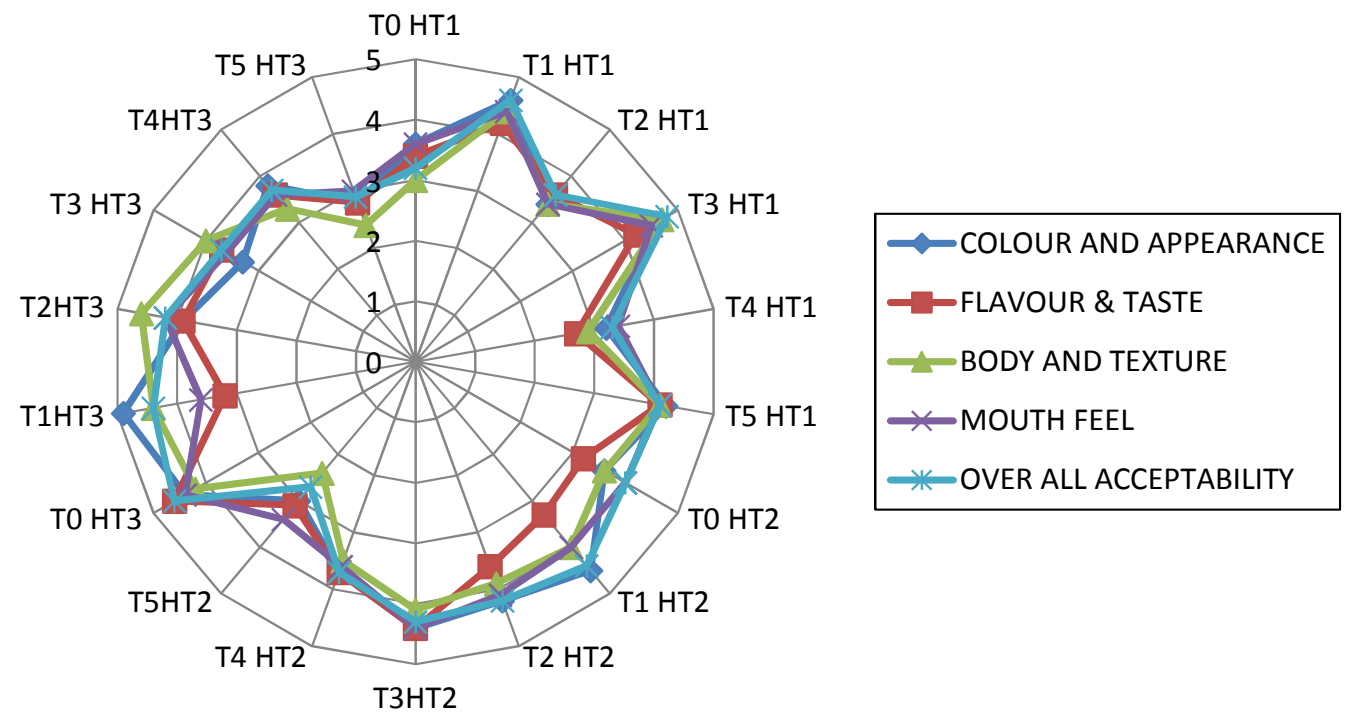

Fig. 3.1. Sensory evaluation of developed cookies 
Table 3.2a. Microbial assay of baked cookies

\begin{tabular}{|c|c|c|c|c|c|c|c|c|c|}
\hline \multirow{2}{*}{$\begin{array}{l}\text { Treatmet } \\
\text { combinations }\end{array}$} & \multicolumn{3}{|c|}{ SPC $\left(10^{3}\right) \mathrm{cfu} / \mathrm{gm}$} & \multicolumn{3}{|c|}{ Yeast and mould (cfu/gm) } & \multicolumn{3}{|c|}{ Coli forms $\left(10^{3}\right) \mathrm{cfu} / \mathrm{gm}$} \\
\hline & $0^{\text {th }}$ day & $15^{\text {th }}$ day & $30^{\text {th }}$ day & $0^{\text {th }}$ day & $15^{\text {th }}$ day & $30^{\text {th }}$ day & $0^{\text {th }}$ day & $15^{\text {th }}$ day & $30^{\text {th }}$ day \\
\hline $\mathrm{T}_{0} \mathrm{HT}_{1}$ & $1.800 \pm 0.844^{b}$ & $2.600 \pm 0.894^{\mathrm{b}, \mathrm{c}}$ & $3.200 \pm 0.837^{b}$ & Nil & Nil & Nil & Nil & Nil & $1.400 \pm 0.548^{b}$ \\
\hline $\mathrm{T}_{1} \mathrm{HT}_{1}$ & $2.400 \pm 0.548^{a, b}$ & $3.200 \pm 0.447^{a, b}$ & $4.600 \pm 0.548^{a}$ & Nil & Nil & Nil & Nil & Nil & $2.800 \pm 0.447^{\mathrm{a}}$ \\
\hline $\mathrm{T}_{2} \mathrm{HT}_{1}$ & $1.400 \pm 0.548^{\mathrm{b}}$ & $1.800 \pm 0.447^{\mathrm{C}}$ & $2.200 \pm 0.837^{b}$ & Nil & Nil & Nil & Nil & Nil & $1.800 \pm 0.837^{\mathrm{a}, \mathrm{b}}$ \\
\hline $\mathrm{T}_{3} \mathrm{HT}_{1}$ & $1.800 \pm 0.837^{\mathrm{b}}$ & $2.600 \pm 0.548^{\mathrm{b}, \mathrm{c}}$ & $2.800 \pm 0.447^{\mathrm{b}}$ & Nil & Nil & Nil & Nil & Nil & $1.320 \pm 0.460^{\mathrm{b}}$ \\
\hline $\mathrm{T}_{4} \mathrm{HT}_{1}$ & $2.200 \pm 0.447^{\mathrm{b}}$ & $2.600 \pm 0.548^{\mathrm{b}, \mathrm{c}}$ & $3.200 \pm 0.447^{\mathrm{b}}$ & Nil & Nil & Nil & Nil & Nil & $1.800 \pm 0.447^{\mathrm{a}, \mathrm{b}}$ \\
\hline $\mathrm{T}_{5} \mathrm{HT}_{1}$ & $3.600 \pm 0.894^{a}$ & $4.200 \pm 0.447^{\mathrm{a}}$ & $4.600 \pm 0.548^{a}$ & Nil & $\mathrm{Nil}$ & $0.200 \pm 0.00^{a}$ & $\mathrm{Nil}$ & $1.480 \pm 0.449^{a}$ & $1.920 \pm 0.1789^{a, b}$ \\
\hline
\end{tabular}

Table 3.2b. Microbial assay of microwaved cookies

\begin{tabular}{|c|c|c|c|c|c|c|c|c|c|}
\hline \multirow{2}{*}{$\begin{array}{l}\text { Treatment } \\
\text { combinations }\end{array}$} & \multicolumn{3}{|c|}{$\operatorname{SPC}\left(10^{3}\right) \mathrm{cfu} / \mathrm{gm}$} & \multicolumn{3}{|c|}{ Yeast and mould (cfu/gm) } & \multicolumn{3}{|c|}{ Coli forms $\left(10^{3}\right) \mathrm{cfu} / \mathrm{gm}$} \\
\hline & $0^{\text {th }}$ day & $15^{\text {th }}$ day & $30^{\text {th }}$ day & $0^{\text {th }}$ day & $15^{\text {th }}$ day & $30^{\text {th }}$ day & $0^{\text {th }}$ day & $15^{\mathrm{th}}$ day & $30^{\text {th }}$ day \\
\hline $\mathrm{T}_{0} \mathrm{HT}_{2}$ & $2.000 \pm 0.707^{b}$ & $3.000 \pm 0.707^{b}$ & $4.000 \pm 0.7071^{a, b}$ & Nil & Nil & Nil & Nil & Nil & $1.480 \pm 0.502^{a}$ \\
\hline $\mathrm{T}_{1} \mathrm{HT}_{2}$ & $2.200 \pm 0.837^{b}$ & $2.800 \pm 0.447^{\mathrm{b}}$ & $3.800 \pm 0.8367^{a, b}$ & Nil & Nil & Nil & Nil & $\mathrm{Nil}$ & $1.880 \pm 0.522^{a}$ \\
\hline $\mathrm{T}_{2} \mathrm{HT}_{2}$ & $1.400 \pm 0.548^{\mathrm{b}}$ & $1.800 \pm 0.447^{\mathrm{C}}$ & $2.200 \pm 0.4472^{\mathrm{C}}$ & Nil & Nil & Nil & Nil & Nil & $1.760 \pm 0.434^{\mathrm{a}}$ \\
\hline $\mathrm{T}_{3} \mathrm{HT}_{2}$ & $2.200 \pm 0.837^{\mathrm{b}}$ & $3.200 \pm 0.447^{\mathrm{b}}$ & $3.400 \pm 0.5477^{\mathrm{b}, \mathrm{c}}$ & Nil & Nil & Nil & Nil & Nil & $2.360 \pm 0.590^{a}$ \\
\hline $\mathrm{T}_{4} \mathrm{HT}_{2}$ & $2.800 \pm 0.447^{\mathrm{a}, \mathrm{b}}$ & $3.00 \pm 0.0000^{\mathrm{b}}$ & $3.800 \pm 1.0954^{\mathrm{a}, \mathrm{b}}$ & Nil & Nil & Nil & Nil & $\mathrm{Nil}$ & $1.360 \pm 0.498^{a}$ \\
\hline $\mathrm{T}_{5} \mathrm{HT}_{2}$ & $4.200 \pm 0.8370^{a}$ & $4.600 \pm 0.548^{\mathrm{a}}$ & $5.200 \pm 0.4472^{a}$ & Nil & Nil & $0.250 \pm 0.434^{\mathrm{a}}$ & $\mathrm{Nil}$ & $1.520 \pm 0.449^{\mathrm{a}}$ & $1.560 \pm 0.518^{a}$ \\
\hline
\end{tabular}

Values are means \pm standard deviation from five parallel observations; Same letters within the same column do not differ significantly ( $p<0.05)$ according to Tukey's test

Table 3.2c. Microbial assay of fried cookies

\begin{tabular}{|c|c|c|c|c|c|c|c|c|c|}
\hline \multirow{2}{*}{$\begin{array}{l}\text { Treatment } \\
\text { combinations }\end{array}$} & \multicolumn{3}{|c|}{ SPC(103) cfu/gm } & \multicolumn{3}{|c|}{ Yeast and mould (cfu/gm) } & \multicolumn{3}{|c|}{ Coli forms $\left(10^{3}\right) \mathrm{cfu} / \mathrm{gm}$} \\
\hline & $0^{\text {th }}$ day & $15^{\text {th }}$ day & $30^{\text {th }}$ day & $0^{\text {th }}$ day & $15^{\text {th }}$ day & $30^{\text {th }}$ day & $0^{\text {th }}$ day & $15^{\text {th }}$ day & $30^{\text {th }}$ day \\
\hline $\mathrm{T}_{0} \mathrm{HT}_{3}$ & $2.200 \pm 0.837^{\mathrm{b}, \mathrm{c}}$ & $3.200 \pm 0.447^{b, c}$ & $4.600 \pm 0.548 a, b$ & Nil & Nil & Nil & Nil & Nil & $1.520 \pm 0.502^{b}$ \\
\hline $\mathrm{T}_{1} \mathrm{HT}_{3}$ & $2.000 \pm 0.707^{b, c}$ & $2.600 \pm 0.548^{c, d}$ & $3.400 \pm 0.548 b, c$ & Nil & Nil & Nil & Nil & Nil & $2.200 \pm 0.447^{\mathrm{a}, \mathrm{b}}$ \\
\hline $\mathrm{T}_{2} \mathrm{HT}_{3}$ & $1.600 \pm 0.548^{c}$ & $2.200 \pm 0.447^{d}$ & $2.600 \pm 0.548 c$ & Nil & Nil & Nil & Nil & Nil & $1.520 \pm 0.502^{b}$ \\
\hline $\mathrm{T}_{3} \mathrm{HT}_{3}$ & $2.400 \pm 0.548^{\mathrm{b}, \mathrm{c}}$ & $3.800 \pm 0.447^{\mathrm{b}}$ & $4.200 \pm 0.447 a, b$ & Nil & Nil & Nil & Nil & $\mathrm{Nil}$ & $2.040 \pm 0.0894^{a, b}$ \\
\hline $\mathrm{T}_{4} \mathrm{HT}_{3}$ & $3.200 \pm 1.095^{\mathrm{a}, \mathrm{b}}$ & $3.600 \pm 0.548^{\mathrm{b}}$ & $4.200 \pm 0.837 a, b$ & Nil & Nil & Nil & Nil & $0.80 \pm 0.748^{b}$ & $1.720 \pm 0.832^{\mathrm{a}, \mathrm{b}}$ \\
\hline $\mathrm{T}_{5} \mathrm{HT}_{3}$ & $4.400 \pm 0.548^{a}$ & $4.800 \pm 0.447^{\mathrm{a}}$ & $5.400 \pm 0.894 a$ & Nil & Nil & $0.12 \pm 0.548^{a}$ & Nil & $1.96 \pm 0.080^{\mathrm{a}}$ & $2.680 \pm 0.460^{\mathrm{a}}$ \\
\hline
\end{tabular}

Values are means \pm standard deviation from five parallel observations; Same letters within the same column do not differ significantly ( $p<0.05)$ according to Tukey's test 


\section{CONCLUSION}

From the present study, it could concluded that the $20 \%$ SPF and $20 \%$ WPC $\left(\mathrm{T}_{3} \mathrm{HT}_{1}\right.$ and $\mathrm{T}_{3}$ HT2)-supplemented cookie samples were nutritionally rich as well as more sensory acceptable product with regardless of both baking and microwave heat treatments. Evaluation results revealed that $40 \% \mathrm{SPF}\left(\mathrm{T}_{1}\right.$ $\mathrm{HT}_{3}$ ) are also good in taste. The standard plate Count, yeast and mould count and coli forms of cookie samples were found within the acceptable limits. Thus, the present our study concludes that the supplementation level of $20 \%$ SPF and $20 \%$ WPC $\left(\mathrm{T}_{3} \quad \mathrm{HT}_{1}\right)$ results are acceptable in the sensory, textural and nutritional characteristics.

\section{ACKNOWLEDGEMENT}

This paper is part of Ph.D research which has been conducted at SHAUTS, Authors are thankful for the university for providing necessary facilites to complete this research work.

\section{COMPETING INTERESTS}

Authors have declared that no competing interests exist.

\section{REFERENCES}

1. Srivastava S, Genitha TR, Yadav V. Preparation and quality evaluation of flour and biscuit from sweet potato. J Food Process Technol. 2012;3:192.

2. Singh S, Riar CS, Saxena DC. Effect of incorporating sweet potato flour to wheat flour on the quality characteristics of cookies. African Journal of Food Science. 2008;2:065-072.

3. Adegunw MO, Sanni LO, Raji RA. Effect of pre-treatment on sweet-potato flour for cookies production. African Journal of Root and Tuber Crops. 2010;8(2):46-50.

4. St-Onge MP, Farnworth ER. Consumption of fermented and non-fermented dairy products. Effect on cholesterol concentrations and metabolism. American Journal of Clinical Nutrition. 2000;71:674681.

5. Peng $X$, Yan $\mathrm{H}$, You Z, Wang $\mathrm{P}$, Wang S. Clinical and protein metabolic efficacy of glutamine granules-supplemented enteral nutrition in severely burned patient. Burn. 2005;31(3):342-346.

6. Miladinov, Vesselin D, Roscetti, Riccardo D. Dietary supplement for renal dialysis patients. US Patent 7067 156; 2006.

7. Tanaka K, Ikeda M, Nozaki. Lactoferrin inhibits hepatitis $C$ virus viremia in patients with chronic hepatitis C: A pilot study. Japanese Journal of Cancer Research. 1999;90:367-371.

8. Eric D, Bastian W, James $H$. Emerging health benefits of whey. Dairy Council Digests. 2003;74:31-36.

9. Keri M. Therapeutic applications of whey protein. Alternative Medical Review. 2004;9:136-156.

10. Agin D, Gallgher D, Wang J. Effect of whey protein and resistance exercise on body cell mass, muscle strength \& quality life in women with HIV AIDS. 2001;15:2431-2440.

11. Hoffiman JR, Falvo MJ. Protein- Which is best. Journal of Sport Science and Medicine. 2004;3:118-130.

12. Ranganna S. Handbook of analysis of and quality control of fruit and vegetable products. $2^{\text {nd }}$ edition Tata Mc Graw hil Publishing Company Ltd, New Delhi; 1986.

13. Kawas ML, Moreira RG. Characterization of product quality attributes of tortilla chips during the frying process. J. Food Eng. 2001;47:97-107.

14. Moreira R, Palau J, Xiuzhi S. Simultaneous heat and mass transfer during the deep fat frying of tortilla chips. Journal of Food Process Engineering. 1995;18:307-320

15. Marcotte M. Heat and mass transfer during baking. WIT Press. 2007;13:239-265.

16. Decareau RV. Microwave food processing equipment throughout the world. Food Technology. 1986;5:99-105.

(C) 2017 Seelam et al.; This is an Open Access article distributed under the terms of the Creative Commons Attribution License (http://creativecommons.org/licenses/by/4.0), which permits unrestricted use, distribution, and reproduction in any medium, provided the original work is properly cited.

Peer-review history:

The peer review history for this paper can be accessed here: http://sciencedomain.org/review-history/19911 